\title{
Genetic damage induced by trophic doses of lead in the neotropical fish Hoplias malabaricus (Characiformes, Erythrinidae) as revealed by the comet assay and chromosomal aberrations
}

\author{
Marta Margarete Cestari ${ }^{1}$, Priscilla Maria M. Lemos ${ }^{1}$, Ciro Alberto de Oliveira Ribeiro ${ }^{2}$, \\ João Ricardo M. Alves Costa $^{2}$, Emilien Pelletier ${ }^{3}$, Marcos V.M. Ferraro ${ }^{1,6}$, Mário Sérgio Mantovani ${ }^{5}$ \\ and Alberto Sergio Fenocchio ${ }^{4,5}$ \\ ${ }^{1}$ Universidade Federal do Paraná, Departamento de Genética, Curitiba, PR, Brazil. \\ ${ }^{2}$ Universidade Federal do Paraná, Departamento de Biologia Celular, Curitiba, PR, Brazil. \\ ${ }^{3}$ Institut des Sciences de la Mer de Rimouski, Allée des Ursulines-Rimouski, Quebec, Canada. \\ ${ }^{4}$ Universidad Nacional de Misiones, Departamento de Genética, Posadas, Misiones, Argentina. \\ ${ }^{5}$ Universidade Estadual de Londrina, Departamento de Biologia Geral, Londrina, PR, Brazil. \\ ${ }^{6}$ Universidade Federal de Santa Catarina, Colégio de Aplicação, Florianópolis, SC, Brazil.
}

\begin{abstract}
The effects of clastogenic or mutagenic agents have rarely been studied in neotropical fish species exposed to contaminated water. In this study, the genetic damage caused by lead in the widely distributed South American fish, Hoplias malabaricus, was assessed using the comet (SCGE) assay and by testing for chromosomal aberrations. Eighteen specimens were acclimatized to laboratory conditions and then chronically exposed to contaminated food by feeding prey (Cyprinus sp.) injected intraperitoneally with doses of inorganic lead adjusted to give a contamination level of $21 \mu \mathrm{g}$ of $\mathrm{Pb}^{2+} . \mathrm{g}^{-1}$ net weight of $H$. malabaricus. Three fish were sampled for chromosomal analysis after four doses (18 days) and another three after eight doses (41 days) of lead and the results then compared with three untreated controls kept under lead-free conditions. An additional six treated fish and three controls were sampled for the comet assay after 13 doses (64 days). Exposure to lead significantly increased the frequency of chromosomal aberrations and the frequency of tailed cell nuclei, the latter indicating DNA damage. These results show that $H$. malabaricus is a useful biological model for screening the clastogenic effects of lead and possibly other xenobiotics. The genetic damage seen here illustrates the need to investigate the potential effects of heavy metals on fish species in South America.
\end{abstract}

Key words: chromosomal aberrations, comet assay, genotoxicity, Hoplias malabaricus, lead, mutagenesis.

Received: September 10, 2002; Accepted: October 21, 2003.

\section{Introduction}

The pollution of freshwater systems has long been considered a serious problem in Europe and North America (Heath, 1995). In contrast, there have been few studies of the effects of heavy metal and organic pollutants on aquatic organisms in neotropical ecosystems. The presence of heavy metals in industrial and municipal wastewater and in mine tailings has generated concern about the potential mutagenic and carcinogenic actions of these substances in aquatic organisms. In numerous aquatic ecosystems in Brazil, native species are often directly threatened by their ex-

Send correspondence to Marta Margarete Cestari, Universidade Federal do Paraná, Departamento de Genética, Caixa Postal 19071, 81531-990 Curitiba, PR, Brazil. E-mail: margaces@ @ufpr.br. posure to water-borne agents or, indirectly, through a contaminated food chain (Oliveira Ribeiro et al., 2000).

The potential for intoxication by lead and its organometallic derivatives in aquatic ecosystems, atmospheric particles, and soil has increased as a result of industrial activities (Pain, 1995). Investigations of the toxic effects of chemical pollutants on fish cells have demonstrated the importance of cytogenetic aberrations as an important indicator for environmental monitoring and assessment. Studies in laboratory animals have shown that exposure to lead at levels $10 \mathrm{mg} \mathrm{Pb}^{2+} . \mathrm{mL}^{-1}$ of blood leads to chromosomal aberrations (tetraploidy, mitotic anomalies, chromatid breaks), and these effects may be related to inteference with the mechanisms of replication, transcription and DNA repair (Goyer and Moore, 1974). Part of this effect on chro- 
mosomes may be related to the ability of lead to form bridges with structural proteins that can adversely affect the degree of chromosomal condensation

Fish are good indicators for assessing the genotoxic and mutagenic effects of xenobiotics and physical agents (Al-Sabti, 1986). Sister chromatid exchange (SCE) tests have been applied to various fish species (Kligerman, 1979; Vigfusson et al., 1983) and the clastogenic effects of carcinogenic-mutagenic chemicals on kidney cells of Cyprinius carpio have been described (Al-Sabti, 1986). The comet assay is useful for evaluating genetic alterations and has been used as a rapid method to monitor genotoxicity in bullheads and carp (Monteith and Vanstone, 1995) and to detect the effects of carcinogens, such as aflatoxins, in trout and channel catfish (Abd-Allah et al., 1999).

The use of neotropical fish to study the mutagenic effects of chemicals is still relatively uncommon (Matsumoto and Cólus, 2000). Hoplias malabaricus is an important predatory freshwater fish widely distributed throughout South America (Lopez and Fenocchio, 1994) and easily adapts to laboratory conditions. Since this species has only a few $(2 n=40$ or $2 n=42)$ biarmed, relatively large chromosomes, it is easy to handle in chromosomal studies. In this study, we used the comet (SCGE) assay and a test for chromosomal aberrations to assess the genetic damage caused by lead fed to $H$. malabaricus. To our knowledge, this is the first report to examine chromosomal damage in vivo following long-term trophic exposure of this species to inorganic lead.

\section{Material and Methods}

\section{Experimental design}

Mature H. malabaricus (average weight $=87.4 \pm 8.9 \mathrm{~g}$ ) were collected from the Canguiri fish farm at the Federal University of Paraná (Curitiba, PR, Brazil). Before being used, the fish were acclimatized individually for 20 days in an aquarium containing well-aerated, dechlorinated water

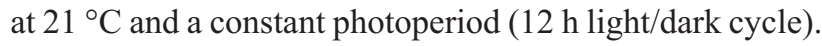
Food (young specimens of Cyprinius sp. 5 days) was provided ad libitum. Twelve $H$. malabaricus were divided into three groups (A, B and D) for treatment with lead and six other fish were used as controls (groups $\mathrm{C}$ and E). For intoxication with lead, the food items were injected intraperitoneally with a solution of $\mathrm{Pb}\left(\mathrm{NO}_{3}\right)_{2}$. The volume of solution injected into the prey fish was adjusted to give a normalized ingested dose of $21 \mu \mathrm{g} \mathrm{Pb}{ }^{2+} . \mathrm{g}^{-1}$ wet weight of $H$. malabaricus. The control group was fed fish injected with distilled water. Groups A and B were exposed to lead for 18 and 41 days, respectively, and the fish then used for chromosomal aberration analysis. Group D fish were exposed for a longer time (64 days, 13 doses) and the genetic effects were evaluated using the comet (SCGE) assay. In this case, group E served as the controls. Fish from each group were anesthetized with $0.02 \%$ MS222 (SIGMA (ethyl-ester.3. aminobenzoic acid). Kidney and blood samples were used for the chromosomal aberrations test and for the comet assay, respectively.

\section{Chromosomal preparations}

Mitotic chromosomes were obtained from short-term cell kidney cultures, as described elsewhere for fish cytogenetics (Fenocchio et al., 1991). Air-dried chromosome slides were stained with 5\% Giemsa in phosphate buffer (pH 6.8). The frequency of chromosomal aberrations was scored by counting approximately 100 metaphase plates per individual. The different types of chromosomal aberrations, i.e., gaps, breaks, and fragments, were grouped into a single category: altered metaphase plates.

\section{Comet assay}

This assay was done essentially as described by Speit and Hartmann (1999) using blood cells collected via the caudal vein into a $5 \mathrm{~mL}$ heparinized syringe. Initially, an aliquot of blood $(10 \mu \mathrm{l})$ was diluted in $1 \mathrm{~mL}$ of fetal calf serum. The slides for microscopy were prepared using $10 \mu \mathrm{L}$ of this cell suspension and $120 \mu \mathrm{L}$ of low melting point agarose at $37^{\circ} \mathrm{C}$ followed by incubation in lysis solution (1 mL of Triton X-100, $10 \mathrm{~mL}$ of DMSO and $89 \mathrm{~mL}$ of stock lysis solution [2.5 M NaCl, $100 \mathrm{mM}$ EDTA, $10 \mathrm{mM}$ Tris, -adjust to $\mathrm{pH} 10$ with $\sim 0.8 \% \mathrm{NaOH}-, 10 \mathrm{mM} \mathrm{Na}-$ lauroyl sarcosine]) for $1 \mathrm{~h}$ in the dark at $8{ }^{\circ} \mathrm{C}$.

After lysis, the slides were placed in buffer $(0.3 \mathrm{~N}$ $\mathrm{NaOH}, 1 \mathrm{mM}$ EDTA, $\mathrm{pH}>13$ ) for $20 \mathrm{~min}$ to unravel the DNA. Electrophoresis was done for $20 \mathrm{~min}$ at $25 \mathrm{~V}$ and $300 \mathrm{~mA}$, after which the slides were neutralized for $15 \mathrm{~min}$ in $0.4 \mathrm{M}$ Tris, fixed in absolute ethanol for $10 \mathrm{~min}$ and stained with ethidium bromide $(0.02 \mu \mathrm{g} / \mathrm{mL})$.

Comet formation was observed with a Nikon epifluorescence microscope (filter B-3A; excitation: $\lambda=420$ $490 \mathrm{~nm}$; emission: $\lambda=520 \mathrm{~nm}$ ) at a magnification of $400 \mathrm{X}$. One hundred cells were analyzed per sample (treated and controls) and were visually classified (Kobayashi et al., 1995) based on the migration of the fragments (tail size) (class 0 - no visible damage, 1 - a short tail smaller than the diameter of the nucleus, 2 - a tail length 1-2 times the diameter of the nucleus, and 3 - a tail length $>$ two times the diameter of the nucleus). The total score for 100 comets was obtained by multiplying the number of cells in each class by the damage class, and ranged from 0 (all undamaged) to 300 (all maximally damaged).

\section{Statistical analysis}

The mean frequencies of the chromosomal alterations in fish exposed to lead for 18 (A) and 41 (B) days and in the control group (C) were compared by one-way analysis of variance (ANOVA), with a value of $\mathrm{p} \ 0.05$ indicating significance. The comet assay data were scored as classes based on the damage seen and were analyzed by the $\chi^{2}$ test 
in which the total number of comets in each treatment was compared with the controls.

\section{Results and Discussion}

Table 1 shows the frequency of chromosomal aberrations in metaphase plates of $H$. malabaricus. Because of the low frequencies observed, and in order to facilitate comparisons, all chromosomal alterations in each group were pooled into a single category.

Control fish showed almost no chromosomal abnormalities $(1.1 \%)$ when compared to those fed lead-contaminated food for 18 or 41 days $(25.6 \%$ and $19.1 \%$ of altered plates, respectively). Despite the low number of specimens used, these differences were significant $(p<0.05)$ because of the low variability among plates. Both treated groups showed an increase in several types of chromosomal abnormalities, including chromatid gaps and breaks, chromosomal fragmentation, chromatin decondensation and pericentric inversions (Table $1,<0.05$ ). Chromatid breaks

Table 1 - Frequency of chromosomal aberrations in metaphase plates of Hoplias malabaricus treated with trophic doses of $\mathrm{Pb}^{2+}$.

\begin{tabular}{lccc}
\hline & $\begin{array}{c}\text { Normal } \\
\text { metaphase } \\
\text { plates }\end{array}$ & $\begin{array}{c}\text { Altered } \\
\text { metaphase } \\
\text { plates }\end{array}$ & $\begin{array}{c}\text { Altered } \\
\text { plates } \\
(\%)\end{array}$ \\
\hline Control (C) & $202 \pm 4.6$ & $2.3 \pm 1.7$ & 1.1 \\
Treatment A (18 days) & $122 \pm 38.8$ & $42 \pm 14.6^{*}$ & 25.6 \\
Treatment B (41 days) & $135.6 \pm 39.1$ & $31.6 \pm 9 . *^{*}$ & 19.1 \\
\hline
\end{tabular}

The frequencies were calculated based on 1800 counts for each group and are the mean \pm SD for three fish per group. ${ }^{*} \mathrm{p}<0.05$ compared to the control group and ${ }^{+} \mathrm{p}<0.05$ compared to treatment $\mathrm{A}$. were the predominant chromosomal aberrations after treatment.

There was a quantitative relationship between the occurrence of chromosomal abnormalities and the ingestion of lead. This metal can alter the genetic material of fish (Al-Sabti, 1985) following bioaccumulation in fish organs (not assessed here). The mutagenic or clastogenic activities of lead are related to disturbances in enzyme regulation that probably affect the replication, translation and repair of genetic material (Goyer and Moore, 1974).

An unexpected significant difference (Table 1 $\mathrm{p}<0.05$ ) was observed between groups A and B, with a greater number of altered metaphase plates after 18 days compared to 41 days. This difference could be related to the activation of appropriate repair mechanisms after a few weeks of exposure, and could counteract the undesired effects of lead on cells. However, this divergence could also reflect the low number of replicates used. A similar finding has been reported using the micronucleus (MN) test. However, in this case, the lower frequency of MN seen in the longest exposed groups was more probably related to the inhibitory effect of lead on the cell cycle than to the induction of cell repair mechanisms (Al-Sabti and Hardig, 1990; Poongothai et al., 1996). Thus, lead may affect both chromosomes and key enzymes involved in metabolic changes in the cell.

To examine the effects of a long-term exposure to lead, fish (group D) were exposed to 13 doses (64 days) and analyzed using the comet assay. Table 2 shows that lead significantly increased the frequency of tailed nuclei in treated fish, thus indicating lead-induced DNA damage. The effects were classified into four classes of damage

Table 2 - DNA damage in Hoplias malabaricus whole blood cells after 64 days of trophic and subchronic exposure to lead.

\begin{tabular}{|c|c|c|c|c|c|c|c|c|}
\hline & \multicolumn{2}{|c|}{ Number of cells } & \multicolumn{4}{|c|}{ Classes } & \multirow[t]{2}{*}{ Scores } & \multirow[t]{2}{*}{$\chi^{2}$} \\
\hline & Analyzed & Tailed cells & 0 & 1 & 2 & 3 & & \\
\hline \multicolumn{9}{|c|}{ Control (group E) } \\
\hline $\mathrm{NC}$ & 100 & 16 & 84 & 16 & 0 & 0 & 16 & \\
\hline $\mathrm{NC}$ & 100 & 6 & 94 & 5 & 0 & 1 & 8 & \\
\hline $\mathrm{NC}$ & 100 & 23 & 77 & 22 & 1 & 0 & 24 & \\
\hline Total & 300 & 45 & 255 & 43 & 1 & 1 & $X=16$ & \\
\hline \multicolumn{9}{|c|}{ Treated (group D) } \\
\hline $\mathrm{Pb}$ & 100 & 17 & 83 & 16 & 0 & 1 & 19 & \\
\hline $\mathrm{Pb}$ & 100 & 66 & 34 & 50 & 16 & 0 & 82 & \\
\hline $\mathrm{Pb}$ & 100 & 58 & 42 & 48 & 8 & 2 & 70 & \\
\hline $\mathrm{Pb}$ & 100 & 15 & 85 & 13 & 2 & 0 & 17 & \\
\hline $\mathrm{Pb}$ & 100 & 56 & 44 & 42 & 10 & 4 & 74 & \\
\hline $\mathrm{Pb}$ & 100 & 54 & 46 & 54 & 0 & 0 & 54 & \\
\hline Total & 600 & 266 & 334 & 223 & 36 & 7 & $X=52.67^{*}$ & 74.804 \\
\hline
\end{tabular}

$\mathrm{X}=$ mean; $\mathrm{Pb}=$ lead; $\mathrm{NC}=$ negative control.

$* \mathrm{p}<0.0001$ compared to negative control. 


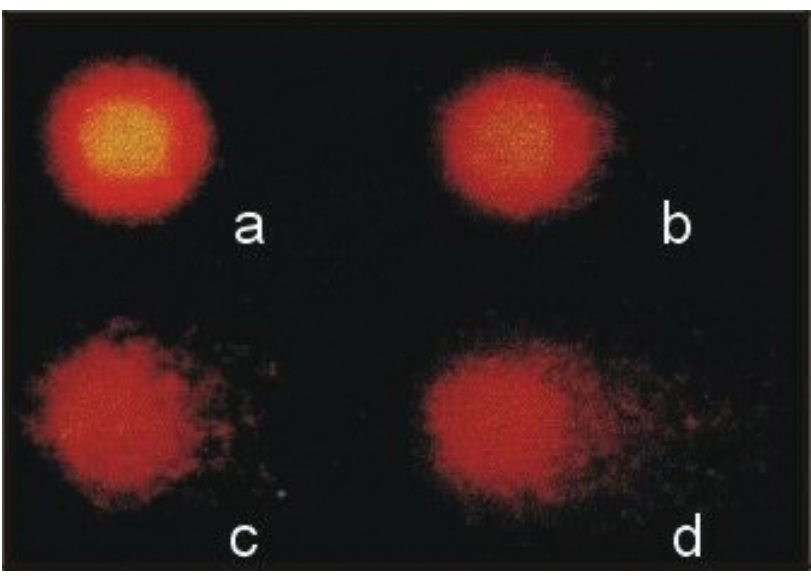

Figure 1 - Effect of long-term trophic exposure to inorganic lead on the appearance of comets in Hoplias malabaricus. Representative individual blood cells from group $\mathrm{C}$, stained with ethidium bromide and photographed using an epifluorescence microscope. (a) Class 0 cells - no damage, (b) Class 1 cells - minor damage, (c) Class 2 cells - moderate damage, and (d) Class 3 cells - major damage.

based on the DNA migration (Figure 1). Some interindividual differences were detected, in agreement with other studies (Mitchelmore and Chipman, 1998). Our results also agreed with those of Abd-Allah et al. (1999) showing that the comet assay is an effective, simple and rapid method for assessing genetic damage caused by heavy metals in fish.

The few reports that have examined fish chromosomal aberrations have been limited to studying the effects of radiation on some cichlid species (Manna and Som, 1982; Som and Manna, 1984). This lack of information may reflect the difficulty in using conventional methods to study species with small chromosomes. A solution to this problem could be the use of certain neotropical cyprinodontiform fish species that have a small number of relatively large chromosomes (Alink et al., 1980). The viability of this approach was confirmed here for H. malabaricus, which has a low diploid number and relatively large, biarmed chromosomes, but no heteromorphic sex chromosomes.

In conclusion, this report is one of the first to use the comet assay to evaluate DNA damage following chronic exposure to $\mathrm{Pb}^{2+}$ in the diet. The results obtained show that the neotropical fish $H$. malabaricus may be a useful natural model for screening the clastogenic effects of lead on fish chromosomes.

\section{Acknowledgements}

This work was supported by the Federal University of Paraná Foundation (FUNPAR). A.S.F. and E.P. were supported by the Conselho Nacional de Desenvolvimento Científico e Tecnológico (CNPq, process no. 305218/02-6) and the National Science and Engineering Research Council of Canada, respectively.

\section{References}

Abd-Allah GA, El-Fayoumi RI, Smith MJ, Heckmann RA and O’Neill KL (1999) A comparative evaluation of aflatoxin $B_{1}$ genotoxicity in fish models using the comet assay. Mutat Res 446:181-188.

Alink GM, Frederix-Wolters EMH, van der Gaaf MA, van de Kerkhoff JFJ and Poels CLM (1980) Induction of sister-chromatid exchanges in fish exposed to Rhine water. Mutat Res 78:369-374.

Al-Sabti K (1985) Frequency of chromosomal aberrations in the rainbow trout, Salmo gairdneri Rch., exposed to five pollutants. J Fish Biol 26:3-9.

Al-Sabti K (1986) Comparative micronucleated erythrocyte cell induction in three cyprinids by five carcinogenic-mutagenic chemicals. Cytobios 47:47-54.

Al-Sabti K and Hardig J (1990) Micronucelus test in fish for monitoring the genotoxic effects of industrial waste products in the Baltic Sea, Sweden. Comp Biochem Physiol 97C:79-82.

Baatrup E (1991) Structural and functional effects of heavy metals on the nervous system, including sense organs, of fish. Comp Biochem Physiol 100C:253-257.

Fenocchio AS, Venere PC, Cesar AC, Dias AL and Bertollo LAC (1991) Short term culture from solid tissues of fishes. Caryologia 44:161-166.

Goyer RA and Moore JF (1974) Cellular effects of lead. Adv Exp Med Biol 48:447-462.

Heath AG (1995) Water Pollution and Fish Physiology. 2nd edition. Lewis Publishers, Boca Raton, pp 1-5.

Kligerman A (1979) Induction of sister chromatid exchanges in the central mudminnow following in vivo exposure to mutagenic agents. Mutat Res 64:205-217.

Kobayashi H, Sugiyama C, Morikawa Y, Hayashi M and Sofuni T (1995) A comparison between manual microscopic analysis and computerized image analysis in the single cell gel electrophoresis. MMS Commun 3:103-115.

Lopez PA and Fenocchio AS (1994) Confirmation of two different cytotypes for the neotropical fish Hoplias malabaricus (Gill, 1903) (Characiformes). Cytobios 80:217-221.

Manna GK and Som RC (1982) Effect of X-rays on the somatic chromosomes of the exotic fish, Tilapia mossambica. Proc Indian Acad Sci 91:121-133.

Matsumoto FE and Cólus IMS (2000) Micronucleus frequencies in Astyanax bimaculatus (Characidae) treated with cyclophosphamide or vinblastine sulfate. Genet Mol Biol 23:489-492.

Mitchelmore CL and Chipman JK (1998) DNA strand breakage in aquatic organisms and the potential value of the comet assay in environmental monitoring. Mutat Res 399:135-147.

Monteith DK and Vanstone J (1995) Comparison of the microgel electrophoresis assay and other assays for genotoxicity in the detection of DNA damage. Mutat Res 345:97-103.

Oliveira Ribeiro CA, Pelletier E, Pfeiffer WC and Rouleau C (2000) Comparative uptake, bioaccumulation and gill damages of inorganic mercury in tropical and nordic freshwater fish. Environ Res 83:286-292.

Pain DJ (1995) Lead in the environment. In: Hoffman DJ, Rattner BA, Burton GA Jr and Cairns J Jr (eds) Handbook of Ecotoxicology. Lewis Publishers, Boca Raton, pp 356-391.

Poongothai K, Shayin S and Usharani MV (1996) Induction of micronuclei in fish by polluted water and heavy metals. Cytobios 86:17-22. 
Som RC and Manna GK (1984) A preliminary study of somatic chromosome aberrations in F1 offprint and their $\mathrm{X}$-irradiated parents of Tilapia (fish). Perspect Cytol Genet 4:331-335.

Speit G and Hartmann A (1999) The comet assay (single cell gel test), a sensitive genotoxicity test for the detection of DNA damage and repair. In: Henderson DS (ed) Methods in Mo- lecular Biology: DNA Repair Protocols - Eukaryotic Systems. v. 113, Totowa, Humana Press, pp 203-211.

Vigfusson NV, Vyse ER, Pernsteiner CA and Dawson RJ (1983) In vivo induction of sister-chromatid exchange in Umbra limi by the insecticides endrin, chlordane, diazinon and guthion. Mutat Res 83:61-68.

Editor Associado: Catarina S. Takahashi 